\title{
Ortaokul Öğretmenlerinin Okul Dışı Çevrelere Gezi Düzenlemeye İlişkin Öz Yeterliklerinin Farklı Değişkenler Açısından İncelenmesi: Tokat İli Örneği*
}

\author{
Müge Pekin ${ }^{\mathrm{a}}$
}

Aykut Emre Bozdoğanb

a Yüksek Lisans Öğrencisi., Tokat Gaziosmanpaşa Üniversitesi, ORCID: 0000-0003-1732-3220

b Prof. Dr., Tokat Gaziosmanpaşa Üniversitesi, ORCID: 0000-0002-5781-9960

\begin{tabular}{|c|c|}
\hline ÖZET & MAKALE BİLGİSİ \\
\hline $\begin{array}{l}\text { Bu araştırmanın amacı, ortaokul öğretmenlerinin okul dışı çevrelere gezi } \\
\text { düzenlenmeye ilişkin öz yeterliklerinin farklı değişkenler açısından incelemektir. } \\
\text { Araştırma betimsel tarama modeline göre gerçekleştirilmiştir. Araştırmada } \\
\text { Tokat il merkezindeki ortaokullarda görev yapan } 117 \text { 'si erkek ve } 91 \text { 'i kadın } \\
\text { olmak üzere toplam } 208 \text { Fen bilimleri, Sosyal bilgiler, Matematik ve Türkçe } \\
\text { öğretmenleri ile gerçekleştirilmiştir. Araştırmada üç kategoriden oluşan ölçme } \\
\text { aracı kullanılmıştır. Arştırmanın genel amacı doğrultusunda cevapları aranan } \\
\text { alt problemlere yönelik ölçek puanından elde edilen verilerin gerekli istatistiksel } \\
\text { çözümleri için betimsel istatistik yöntemlerinden (f) frekans, (\%) yüzde ve (x) } \\
\text { aritmetik ortalama kullanılmıştır. Yapılan araştırmada ölçekten elde edilen } \\
\text { veriler normal dağılım gösterdiği için parametrik analiz yöntemlerinden } \\
\text { ANOVA ve t-testinden yararlanılmıştır. Açık uçlu sorular ise içerik analizine tabi } \\
\text { tutulmuştur. Araştırma sonucunda öğretmenlerin gezi düzenleme noktasında } \\
\text { kendilerini yeterli gördükleri sonucuna ulaşılmıştır. Bununla birlikte } \\
\text { öğretmenlerin gezi düzenlemeye yönelik öz yeterlik inanç puanları; eğitim } \\
\text { durumu değişkeninde farklılaşırken, cinsiyet, mezun oldukları bölüm, gezi } \\
\text { düzenleme sıklığ1 ve hizmet süresi değişkenlerinde farklılaşmadığı görülmüştür. } \\
\text { Farklı branşlardaki öğretmenlerin okul dışı̈ öğrenme ortamları olarak en sık okul } \\
\text { bahçesini kullandıkları belirlenmiştir. Öğretmenler gezi düzenleme faaliyetleri } \\
\text { süresince öğrenci, veli ve kurumlardan izin alma, öğrencilerin kontrolünü ve } \\
\text { güvenliğini sağlama ve öğrencilerden gezi dönütü alma gibi sorunlar yaşadıkları } \\
\text { tespit edilmiştir. }\end{array}$ & $\begin{array}{l}\text { Makale Geçmişi } \\
\text { Gönderim tarihi: } \\
\text { 23.06.2021 } \\
\text { Kabul tarihi: } \\
03.08 .2021 \\
\text { Anahtar Kelimeler } \\
\text { Ortaokul } \\
\text { Öğretmenleri, } \\
\text { Okul Dışı Öğretim } \\
\text { Ortamları, } \\
\text { Öz-Yeterlik İnancı }\end{array}$ \\
\hline
\end{tabular}

Atıf Bilgisi: Pekin, M. ve Bozdoğan, A.E. (2021). Ortaokul öğretmenlerinin okul dişı çevrelere gezi düzenlemeye ilişkin öz yeterliklerinin farklı değişkenler açısından incelenmesi: Tokat ili örneği. Uluslararası Türk Ĕ̆itim Bilimleri Dergisi, 10 (17), 114-133.

Sorumlu yazar: Müge Pekin, e-posta: mugepekinpekin35@gmail.com

"Bu çalışma birinci yazarın ikinci yazar danışmanlığında gerçekleştirdiği yüksek lisans tezinden üretilmiştir. Bu çalışmada 2020 yılı öncesi toplanan veriler kullanıldığı için etik kurul onayı alınmamakla birlikte Tokat Valiliği İl Milli Eğitim Müdürlüğü'nden 06.11.2018 tarihli 27001677-44E.20892185 sayılı yazı ile izin alınarak gerçekleştirilmiştir. 


\title{
Examining Secondary School Teachers' Self-Efficacy In Organizing Trips To Out-Of-School Environments In Terms Of Different Variables: Sample of Tokat Province*
}

\author{
Müge Pekin ${ }^{\mathrm{a}}$ \\ Aykut Emre Bozdoğan $b$ \\ a Graduate Student., Tokat Gaziosmanpaşa University, ORCID: 0000-0003-1732-3220 \\ b Prof. Dr., Tokat Gaziosmanpaşa University, ORCID: 0000-0002-5781-9960
}

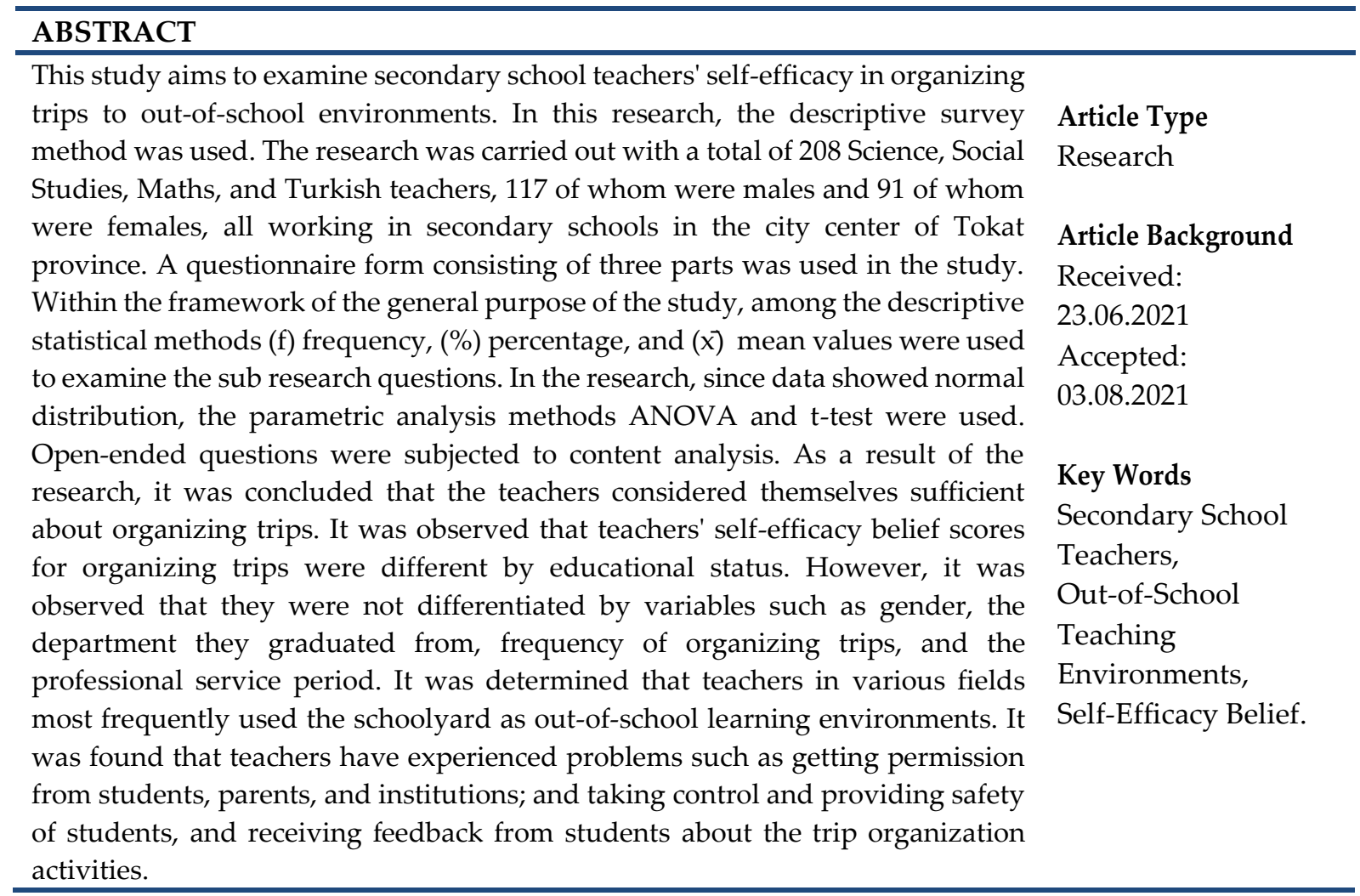

To cite this article: Pekin, M. \& Bozdoğan, A.E. (2021). Examining secondary school teachers' self-efficacy in organizing trips to out-of-school environments in terms of different variables: Sample of Tokat province. International Journal of Turkish Educational Sciences, 10 (17), 114-133.

Corresponding Author: Müge Pekin, e-mail: mugepekinpekin35@gmail.com

\footnotetext{
* This study is derived from the master's thesis prepared by the first author under the advice of second author. Since the data collected before 2020 were used in this study, although the approval of the ethics committee was not obtained, it was carried out with the permission of the Provincial Directorate of National Education of Tokat Governorship with the letter dated 06.11.2018 and numbered 27001677-44-E.20892185.
} 


\section{Giriş}

Eğitim ve öğretimin önemli unsurlarından biri okullar olmakla birlikte günümüzde bu faaliyetler sadece okullarda gerçekleşen bir süreçten ziyade yarar sağlayan her türlü okul dış1 ortamlardan yararlanılabilen bir sürece dönüşmüştür (Karamustafaoğlu ve Ermiş, 2020; Saraç, 2017). Çünkü öğrencilerin sadece sınıf içi uygulamalarla öğrendikleri bilgileri günlük hayata aktarmaları yeterli düzeyde olmamaktadır ve toplumun beklentilerine cevap verememektedir (Avc1 ve Gümüş, 2019; Usta \& Korkmaz, 2010). Bu nedenle okul dış1 eğitim günümüzde önem kazanarak Milli Eğitim Bakanlığı'nın öğretim programlarında da yer almakta ve yapılacak olan farklı etkinliklerin imkânlar dâhilinde bu öğrenme ortamları içerisinde yapılması gerektiği vurgulanmaktadır (MEB, 2018). Literatürde okul dişı eğitimlerin müzelerde, hayvanat ve botanik bahçelerinde, bilim merkezlerinde, doğa alanlarında, fabrikalarda, resmi dairelerde, sergilerde, arkeolojik kazı alanlarında, atölyelerde, tarihi yapılarda, savaş alanlarında ve okul bahçelerinde yapılabileceği belirtilmektedir (Erten ve Taşçı, 2016; MEB, 2018; Okur, Uzoğlu ve Bozdoğan, 2019; Sturm ve Bogner, 2010). Eschenhagen, Katmann ve Rodi (2008)'de tarım alanları ile doğa koruma (milli park) alanlarının da okul dışı öğrenme ortamı içerinde yer aldığını vurgulamaktadır. Bu ortamlar tüm disiplin alanları için öğrenme ortamı sağlamaktadır. Özellikle fen bilimleri ve sosyal bilgiler dersinin konularının yaşamın içerisinde yer alması ve her durumda karşılaştığımız pek çok olayı ve olguyu içermesi nedeniyle okul dışı ortamları daha fazla kullanması gerekmektedir (Erten ve Taşçı, 2016). Bu derslerdeki konuların günlük hayatla ilişkilendirilmeden öğretilmeye çalışılması ve bilgilerin ilk elden aktarılması öğrencilerin anlamlı ve kalıcı öğrenmenin gerçekleşmesini zorlaştırır. Çünkü konuların yaşamın içindeki örneklerle bağlantı kurularak öğretilmesi, öğrencilerin gerçek ortaminda bulunan materyalleri gözlemleyerek, keşfederek ve dokunarak öğrenmesi bilginin kalıcı izli olmasını destekler. Ayrıca bu ortamlar öğrencilerin öğrenmelerini cesaretlendirmekte (Melber ve Abraham, 1999) ve okuldaki eğitimlerine de destek olmaktadır (Gerber, Marek ve Cavallo, 2001). Bozdoğan (2008)' nın çalışmasında da benzer şekilde okul dışı öğrenme ortamlarından birisi olan bilim merkezlerindeki deney düzenekleri ile gerçekleştirilen faaliyetlere katılan öğrencilerin fen dersine olan ilgilerinin ve akademik başarılarının arttığı belirlenmiştir. Bu nedenle çocukların araştırma becerilerini kazanmaları, tabii meraklarının ve soru sorma becerilerinin geliştirilmesi için okul dışı öğrenme ortamlarının oluşturulması oldukça önemlidir (Sontay, Tutar ve Karamustafaoğlu, 2016).

Okul dışı öğrenme ortamlarında gerçekleşecek öğretim faaliyetlerinin faydalı olması, öğretmenin prosedürü doğru biçimde planlaması ve yönlendirmesiyle mümkün olmaktadır. Fakat okul dişı öğretimleri düzenli bir şekilde gerçekleştirmek öğretmenler için oldukça zordur. Çünkü öğretmenlerin ideal içeriğin nasıl bir yerde, hangi metot kullanarak öğretileceğini planlamış, kendi görevlerini benimseyen ve öğretim sürecini programlamış olması gerekmektedir (Sarığlan ve Küçüközer, 2017). Bu kabiliyet ise ancak öz yeterliliğe sahip olan öğretmenlerin yapabileceği bir uygulamadır. Bandura (1997)'ya göre, öz yeterlilik, bireyin herhangi bir performans durumunu göstermek için gereken faaliyetleri koordine edip, bu faaliyetleri eksiksiz bir biçimde ortaya koyabileceğine dair kendisine olan inancıdır. Yani öz-yeterlilik bireyin kendisi için çaba ortaya koymasını gerektiren ve istenmeyen bir olayla karşılaştığında bunu çözebilmesine yönelik inançları olarak da açılanabilmektedir (Luszczynska, Gutiérrez-Doña ve Schwarzer, 2005). Burada bireyin sarfettiği çaba ve yeteneklerinden çok bu çabalarına ve yeteneklerine olan inancı önemlidir. Öz yeterlilik, 
bireyin "sahip olduğu tecrübeler, dolaylı edinilen öğrenmeler ve pozitif dönütler" gibi durumlardan oldukça etkilenmektedir (Yıldırım ve İlhan, 2010). Bu saptamadan yola çıkılarak ortaokul öğretmenlerinin okul dışı çevrelere gezi düzenlemeye yönelik öz yeterlilik inançlarının farklı değişkenler açısından nasıl etkilendiğinin belirlenmesi önem arz etmektedir. Literatür incelendiğinde fen bilimleri öğretmenlerinin (Çiçek ve Saraç, 2017; Sontay ve Karamustafaoğlu, 2017), fen bilimleri öğretmen adaylarının (Bozdoğan, 2016; Bozdoğan, 2012; Gürsoy, 2018), sınıf öğretmeni adaylarının (Demirel, 2020; Hamurcu, Karc1, Göbeklioğlu, Aymak, Atalay ve Topaloğlu, 2019), okul öncesi öğretmenlerinin (İşlek, 2019; Temel ve Kölemen, 2021) ve sınıf öğretmenlerinin (Uzbilir Özçelik, 2018) okul dışı çevrelere eğitim amaçlı gezi düzenleme öz yeterlik inançları incelenmesine rağmen, ortaokul öğretmenlerinin okul dışı çevrelere gezi düzenlemeye ilişkin öz yeterliklerinin farklı değişkenler açısından incelenmesiyle ilgili bir çalışmaya rastlanmamıştır.

Literatürdeki bu eksikliği giderebilmek için yapılan bu çalışma ile ortaokul öğretmenlerinin okul dışı çevrelere yönelik gezi düzenleyebilme öz yeterliklerinin farklı değişkenler açısından incelenmesi planlanmış ve aşağıdaki sorulara yanıtlar aranmıştır;

1. Araştırmaya katılan ortaokul öğretmenlerinin okul dışı çevrelere eğitim amaçlı gezi düzenleyebilme öz-yeterlikleri ile cinsiyetleri arasında anlamlı bir fark var mıdır?

2. Araştırmaya katılan ortaokul öğretmenlerinin okul dışı çevrelere eğitim amaçlı gezi düzenleyebilme öz-yeterlikleri ile mezun oldukları fakülte arasında anlamlı bir fark var midır?

3. Araştırmaya katılan ortaokul öğretmenlerinin okul dışı çevrelere eğitim amaçlı gezi düzenleyebilme öz-yeterlikleri ile lisansüstü eğitim durumu arasında anlamlı bir fark var midır?

4. Araştırmaya katılan ortaokul öğretmenlerinin okul dışı çevrelere eğitim amaçlı gezi düzenleyebilme sıklıkları nedir?

5. Araştırmaya katılan ortaokul öğretmenlerinin okul dışı çevrelere eğitim amaçlı gezi düzenleyebilme öz-yeterlikleri ile gezi düzenleyebilme sıklıkları arasında anlamlı bir fark var midir?

6. Araştırmaya katılan ortaokul öğretmenlerinin okul dışı çevrelere eğitim amaçlı gezi düzenleyebilme öz-yeterlikleri ile branşları arasında anlamlı bir fark var mıdır?

7. Araştırmaya katılan ortaokul öğretmenlerinin okul dışı çevrelere eğitim amaçlı gezi düzenleyebilme öz yeterlikleri ile hizmet süreleri arasında anlamlı bir fark var mıdır?

8. Araştırmaya katılan ortaokul öğretmenlerinin branşlarına göre okul dişı öğrenme ortamlarını kullanma durumları nedir?

9. Araştırmaya katılan ortaokul öğretmenlerinin gezi düzenleme sürecinde kaygı yaşadıkları durumlar nelerdir? 


\section{Yöntem}

\section{Araştırmanın Modeli}

Çalışmada nicel araştırma yöntemlerinden betimsel tarama yöntemi kullanılmıştır. Bu yöntem verilen bir durumu aydınlatmak, standartlar doğrultusunda değerlendirmeler yapmak ve olaylar arasındaki olası ilişkileri ortaya çıkarmak için yürütülür ve bu tür araştırmalarda asıl amaç incelenen durumu etraflıca tanımlamak ve açılamaktır (Çepni, 2007). Yapılan bu çalışmada da ortaokul öğretmenlerinin okul dışı çevrelere yönelik gezi düzenleyebilme öz yeterliklerinin farklı değişkenler açısından incelenip durumun etraflıca tanımlanması için bu yöntem seçilmiştir.

\section{Evren ve Örneklem}

Araştırmanın ulaşılabilir evrenini Tokat ili merkez ortaokullarında görev yapan Fen Bilimleri öğretmenleri, Sosyal Bilgiler öğretmenleri, Matematik öğretmenleri ve Türkçe öğretmenleri oluşturmaktadır. Araştırmanın örneklemini belirlemek için Tokat İl Milli Eğitim Müdürlüğü'nden Tokat ilindeki merkez ve merkeze bağlı köy okullarının isimleri alınmıştır. Araştırmanın örneklemi ise Tokat ilinde görev yapan Fen bilimleri öğretmenleri, Matematik öğretmenleri, Sosyal Bilgiler öğretmenleri ve Türkçe öğretmenleri arasından tabakalı örneklem ile seçilen toplam 208 öğretmenden oluşmaktadır. Tablo 1'de örneklem cinsiyet, mezun olduğu fakülte, branş, lisansüstü eğitim durumu ve hizmet yılına göre gruplandırılmıştır.

Tablo 1. Ortaokul Öğretmenlerinin Demografik Özellikleri

\begin{tabular}{llc}
\hline Demografik Bilgiler & Kategoriler & $\mathrm{f}$ \\
\hline Cinsiyet & Erkek & 117 \\
Mezun Olduğu Fakülte & Kadın & 91 \\
& Eğitim Fakültesi & 191 \\
& Fen Edebiyat Fakültesi & 17 \\
Branş & Fen Bilimleri & 49 \\
& Türkçe & 59 \\
& Sosyal Bilgiler & 46 \\
Lisansüstü Eğitim & Matematik & 54 \\
Hizmet Süreleri & Yapan & 43 \\
& Yapmayan & 165 \\
& $1-5$ yıl & 23 \\
& $6-10$ yıl & 62 \\
& $11-15$ yıl & 57 \\
& $16-20$ yıl & 43 \\
\hline
\end{tabular}


Tablo 1 incelendiğinde katılımcıların 117'sinin erkek, 91'inin kadın öğretmenlerden oluştuğu görülmektedir. Öğretmenlerin 191'i Eğitim Fakültesi, 17'si ise Fen Edebiyat Fakültesi mezunudur. 208 öğretmenden 49'u Fen Bilimleri, 59'u Türkçe, 46's1 Sosyal Bilgiler ve 54'ü Matematik öğretmeni olup bunlardan 43'ünün lisansüstü eğitim (yüksek lisans, doktora) yaptığı görülmektedir. Araştırmaya katılan öğretmenlerin 23'ünün 1-5 yıl, 62'sinin 6-10 yıl, 57 'sinin 11-15 yıl, 43'ünün 16-20 yıl ve 23'ünün ise 21 yıl ve üstü hizmet yaptı̆̆ görülmektedir.

\section{Veri Toplama Araç ve Teknikleri}

Bu çalışmada 2020 yılı öncesi toplanan veriler kullanıldığı için etik kurul onayı alınmamakla birlikte Tokat Valiliği İl Milli Eğitim Müdürlüğü'nden 06.11.2018 tarihli 27001677-44E.20892185 sayılı yazı ile izin alınarak gerçekleştirilmiştir. Araştırmada üç bölümden oluşan anket formu kullanılmıştır. Anket formunun birinci kısmında, ortaokul öğretmenlerinin demografik özelliklerini tespit etmek için araştırmacı tarafından hazırlanan ve 5 kapalı uçlu sorudan oluşan demografik bilgi soruları yer almaktadır. Anket formunun ikinci kısmında ise öğretmenlerin okul dışı çevrelere ilişkin görüşlerinin alındığ1 2 kapalı uçlu ve 2 açık uçlu soru olmak üzere toplam 4 soru bulunmaktadır. Anket formunun üçüncü bölümünde ise Bozdoğan (2015) tarafından geliştirilen “Okul Dışı Çevrelere Eğitim Amaçlı Gezi Düzenleyebilme ÖzYeterlik İnancı Ölçeği” (EAGÖÖ) kullanılmıştır. Ölçekteki olumsuz maddelerin puanlaması ise ters olarak yapılmıştır. Ölçeğin Cronbach Alfa güvenilirlik katsayısı 0.93, Guttmann SplitHalf değeri 0.89 ve Spearman Brown güvenirlik katsayısı da $0.89^{\prime}$ dur.

\section{Toplanan Verilerin Analizi}

Verileri toplamak için, öncelikle Tokat İl Milli Eğitim Müdürlüğünden 2018-2019 Eğitim Öğretim yılında Tokat merkez ortaokullarında uygulama yapabilmek ve veri toplama araçlarını kullanabilmek için gerekli izinler alınmıştır. Hazırlanan ölçme aracı 30 merkez ilköğretim okulundaki öğretmenlere 2018-2019 eğitim öğretim yılının Aralık ayında uygulanmaya başlanmıştır. Her anket formu numaralandırılmıştır. Veri girişi tamamlandıktan sonra yanlış giriş olup olmadığı, kayıp değerlerin oranı ve uç değerler kontrol edilerek veriler analize hazır hale getirilmiştir. Araştırmanın genel amacı çerçevesinde cevapları aranan alt problemlere yönelik ölçek kullanılarak toplanacak verilerin gerekli istatistiksel çözümleri için betimsel istatistik yöntemlerinden (f) frekans, (\%) yüzde ve (x) aritmetik ortalama kullanılmıştır. Yapılan araştırmada ölçekten elde edilen veriler normal dağılım gösterdiği için parametrik analiz yöntemlerinden ANOVA ve $T$ testinden yararlanılmıştır. Sayısal sonuçlarla ilgili veriler tablolar haline getirilip yorumlanmıştır. Bağımsız değişkenler arasında anlamlı bir farklılık olup olmadığı $\alpha=0.05$ değerine göre tespit edilmiştir. Araştırmada Kullanılan Ölçeğe İlişkin Shapiro-Wilk Normal Dağılım testi yapılmış ve Tablo 2'de sunulmuştur.

Tablo 2. Araştırmada Kullanılan Ölçeğe İlişkin Shapiro-Wilk Normal Dağılım Test Sonuçları

\begin{tabular}{lccc} 
Uygulanan Test & Shapiro-Wilk & $\mathrm{df}$ & $\mathrm{p}$ \\
Öz-yeterlik Ölçeği & .991 & 207 & .257 \\
\hline
\end{tabular}

Tablo 2 incelendiğinde araştırmada kullanılan öz yeterlik ölçeğinden elde edilen verilerin çarpıklık katsayısının $(0,164)$, basıklık katsayısının ise $(0,242)$ olduğu görülmüştür. Yine 
yapılan analizlerde verilerin Shapiro-Wilk normal dağılım testi sonuçları incelendiğinde elde edilen verilerin normal dağılım gösterdiği belirlenmiştir $(\mathrm{p}>0.05)$. Bu sonuç ölçek puanlarının normal dağılım gösterdiğini ortaya koymaktadır.

Araştırmada kullanılan açık uçlu soruların analizi ise içerik analizine tabi tutulmuştur. İçerik analizi; metinlerin düzenlenmesi, tasnif edilenlerin kendi içinde kıyaslanması ve tamamlanan bütün bu aşamalardan yola çıkılarak sonuç elde etmeye yarayan bir araştırma metodudur. Metinlerde sık tekrar eden verileri elimine etmek, tema ve kodlar yoluyla daha anlaşılır kılmak için kullanılmıştır (Gülen, 2021). Bu kapsamda analizler yapılırken ana başlık ve alt kategoriler oluşturulmuş ve görüşlerin tekrarlanma sıklığına göre gruplandırılmıştır. Öğretmen görüşleri de bulgular bölümünde sunulmuştur. Öğretmenlerin görüşleri belirtilirken cinsiyet ve anket numaraları verilmiştir. Erkek öğretmenler için ", Kadın öğretmenler için ' $K$ ' kısaltmaları kullanılmıştır ve anket numaraları göre (K13), (K25), (K1), (K67) veya (E125), (E42), (E37), (E5) şeklinde ifade edilmiştir.

\section{Bulgular}

Araştırmaya katılan ortaokul öğretmenlerinin, cinsiyetlerine, mezun oldukları fakülte ve lisansüstü eğitim durumlarına göre okul dışı çevrelere eğitim amaçlı gezi düzenleyebilme özyeterlik puanları arasında anlamlı bir farkın olup olmadığı incelenmiş ve Tablo 3 'te sunulmuştur.

Tablo 3. Öğretmenlerin Okul Dışı Çevrelere Eğitim Amaçlı Gezi Düzenleyebilme ÖzYeterlikleri ile Cinsiyet, Mezun Oldukları Fakülte ve Lisansüstü Eğitim Durumu Değişkenlerine İlişkin t-Testi Sonuçları

\begin{tabular}{|c|c|c|c|c|c|c|c|c|}
\hline $\begin{array}{l}\text { Bağımli } \\
\text { değişken }\end{array}$ & $\begin{array}{c}\text { Bağımsız } \\
\text { değişkenler }\end{array}$ & & $\mathrm{N}$ & $\bar{x}$ & SS & $\mathrm{Sd}$ & $\mathrm{t}$ & $\mathrm{p}$ \\
\hline \multirow{6}{*}{ Öz-yeterlik } & \multirow{2}{*}{ Cinsiyet } & Erkek & 117 & 3.76 & 0.55 & \multirow{2}{*}{206} & \multirow{2}{*}{.78} & \multirow{2}{*}{.44} \\
\hline & & Kadın & 91 & 3.70 & 0.48 & & & \\
\hline & \multirow{2}{*}{$\begin{array}{c}\text { Mezun Olunan } \\
\text { Fakülte }\end{array}$} & Eğitim F. & 191 & 3.73 & 0.51 & \multirow{2}{*}{206} & \multirow{2}{*}{0.41} & \multirow{2}{*}{.68} \\
\hline & & Fen Edebiyat F. & 17 & 3.68 & 0.54 & & & \\
\hline & \multirow{2}{*}{$\begin{array}{l}\text { Lisans Üstü } \\
\text { Eğitim }\end{array}$} & Yapan & 43 & 3.88 & 0.60 & \multirow{2}{*}{206} & \multirow{2}{*}{2.17} & \multirow{2}{*}{$.031^{*}$} \\
\hline & & Yapmayan & 165 & 3.69 & 0.48 & & & \\
\hline
\end{tabular}

Tablo 3 incelendiğinde erkek öğretmenlerin okul dişı çevrelere eğitim amaçlı gezi düzenleyebilme öz-yeterlik puan ortalamalarının $\left(\bar{x}^{-}=3.76\right)$, kadın öğretmenlerin puan ortalamalarından daha yüksek ( $\overline{\left.x^{-}=3.70\right)}$ bulunmuştur. Bununla birlikte öğretmenlerin okul dışı çevrelere eğitim amaçlı gezi düzenleyebilme öz yeterlik puanları ile cinsiyet değişkeni arasında anlamlı bir fark olmadığı tespit edilmiştir $\left(\mathrm{t}_{(206)}=0.78, \mathrm{p}=.44\right)$. Bununla birlikte Eğitim Fakültesinden mezun olan ortaokul öğretmenlerinin okul dışı çevrelere eğitim amaçlı gezi

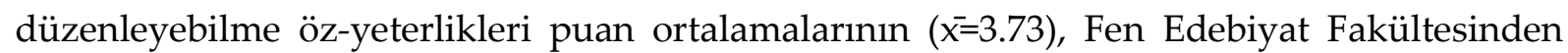
mezun olan ortaokul öğretmenlerin puan ortalamalarından daha yüksek $(\bar{x}=3.68)$ 
bulunmuştur. Ancak öğretmenlerin okul dişı çevrelere eğitim amaçlı gezi düzenleyebilme öz yeterlik puanları ile mezun olunan fakülte değişkeni arasında anlamlı bir fark olmadığı tespit edilmiştir $\left(t_{(206)}=0.41, p=.68\right)$. Lisansüstü eğitim yapan ortaokul öğretmenlerinin okul diş1 çevrelere eğitim amaçlı gezi düzenleyebilme öz-yeterlikleri puan ortalamalarının ( $\bar{x}=3.88)$, lisansüstü eğitim yapmayan ortaokul öğretmenlerinin puan ortalamalarından daha yüksek ( $\overline{x=3.69)}$ bulunmuştur. Öğretmenlerin okul dışı çevrelere eğitim amaçlı gezi düzenleyebilme öz yeterlik puanları ile lisansüstü eğitim yapma değişkeni arasında anlamlı bir farkın olduğu tespit edilmiştir $\left(t_{(206)}=2.17, p=.031\right)$. Bu farkın lisansüstü eğitim yapan öğretmenler lehine olduğu görüşmüştür.

Öğretmenlerin okul dışı çevrelere eğitim amaçlı gezi düzenleyebilme öz yeterlikleri ile gezi düzenleyebilme sıklığı arasındaki ilişki incelenmiş ve Tablo 4 ve Tablo 5'de sunulmuştur.

Tablo 4. Öğretmenlerin Okul Dışı Çevrelere Eğitim Amaçlı Gezi Düzenleyebilme Öz yeterlikleri ile Düzenleyebilme Sıklığına İlişkin Betimsel İstatistikler

\begin{tabular}{lccc}
\hline Gezi Düzenleme Sıklı̆̆1 & \multicolumn{3}{c}{ Öz-yeterlik } \\
\hline Ayda Bir Kez & $\mathrm{N}$ & $\overline{\mathrm{x}}$ & SS \\
Her Dönem & 12 & 3.92 & 0.64 \\
Her Sene & 38 & 3.80 & 0.39 \\
Düzensiz aralıklarla & 73 & 3.77 & 0.49 \\
Toplam & 85 & 3.63 & 0.54 \\
\hline
\end{tabular}

Tablo 4 incelendiğinde ortaokul öğretmenlerinin 12'sinin ayda bir kez, 38'nin her dönem, 73'ünün her sene, 85'inin düzensiz aralıklarla gezi düzenlediği görülmektedir. Ayda bir kez gezi düzenleyen öğretmenlerin okul dışı çevrelere eğitim amaçlı gezi düzenleyebilme öz yeterlikleri en yüksek ortalamaya $(\bar{x}=3.92)$, düzensiz aralıklarla gezi düzenleyen öğretmenlerin ise en düşük ortalamaya $(\overline{x=3.63)}$ sahip olduğu görülmektedir.

Tablo 5. Öğretmenlerin Okul Dışı Çevrelere Eğitim Amaçlı Gezi Düzenleyebilme Öz yeterlikleri ile Gezi Düzenleyebilme Sıklığına İlişkin ANOVA Testi Sonuçları

\begin{tabular}{lccccc}
\hline & $\begin{array}{c}\text { Kareler } \\
\text { Toplamı }\end{array}$ & Sd & $\begin{array}{c}\text { Kareler } \\
\text { Ortalaması }\end{array}$ & F & p \\
\hline Gruplar Arası & 1.49 & 3 & .49 & 1.93 & .12 \\
Gruplar İçi & 52.51 & 204 & 26 & & \\
Toplam & 54.01 & 207 & & & \\
\hline
\end{tabular}

Tablo 5 incelendiğinde ortaokul öğretmenlerinin okul dışı çevrelere eğitim amaçlı gezi düzenleyebilme öz yeterlikleri ile gezi düzenleyebilme sıklığı arasında anlamlı bir fark olmadığ1 görülmüştür $\left[\mathrm{F}_{(3-204)}=1.93, \mathrm{p}>\right.$.05].

Öğretmenlerin okul dışı çevrelere eğitim amaçlı gezi düzenleyebilme öz yeterlikleri ile 
Ortaokul Öğretmenlerinin Okul Dışı Çevrelere Gezi Düzenlemeye İlişkin Öz Yeterliklerinin Farklı Değişkenler Açısından İncelenmesi: Tokat İli Örneği

branşları arasındaki ilişki incelenmiş ve Tablo 9'da ve Tablo 10' da sunulmuştur.

Tablo 6. Öğretmenlerin Okul Dışı Çevrelere Eğitim Amaçlı Gezi Düzenleyebilme ÖzYeterlikleri ile Branş Değişkenine İlişkin Betimsel İstatistikler

\begin{tabular}{lccc}
\hline Branş & & Öz-yeterlik & \\
& $\mathrm{N}$ & $\overline{\mathrm{x}}$ & $\mathrm{SS}$ \\
\hline Fen Bilimleri & 49 & 3.64 & 0.50 \\
Türkçe & 59 & 3.75 & 0.50 \\
Sosyal Bilgiler & 46 & 3.85 & 0.58 \\
Matematik & 54 & 3.66 & 0.44 \\
Toplam & 208 & 3.72 & 0.51 \\
\hline
\end{tabular}

Tablo 6 incelendiğinde Fen Bilimleri öğretmenlerinin okul dışı çevrelere eğitim amaçlı gezi düzenleyebilme öz-yeterlik puan ortalamalarının $(\bar{x}=3.64)$, Türkçe öğretmenlerinin puan ortalamalarının $(\bar{x}=3.75)$, Sosyal Bilgiler öğretmenlerinin puan ortalamalarının $(\bar{x}=3.85)$ ve Matematik öğretmenlerinin puan ortalamalarının ise $(\bar{x}=3.66)$ olduğu görülmüştür.

Tablo 7. Öğretmenlerin Okul Dışı Çevrelere Eğitim Amaçlı Gezi Düzenleyebilme ÖzYeterliklerinin Branş Değişkenine İlişkin ANOVA Testi Sonuçları

\begin{tabular}{lccccc}
\hline & $\begin{array}{c}\text { Kareler } \\
\text { Toplamı }\end{array}$ & sd & $\begin{array}{c}\text { Kareler } \\
\text { Ortalamas }\end{array}$ & F & p \\
\hline Gruplar Arası & 1.30 & 3 & 0.43 & 1.67 & .17 \\
Gruplar İçi & 52.71 & 204 & 0.25 & & \\
Toplam & 54.01 & 207 & & & \\
\hline
\end{tabular}

Tablo 7 incelendiğinde ortaokul öğretmenlerinin branşlarına göre okul dışı çevrelere eğitim amaçlı gezi düzenleyebilme öz-yeterlikleri arasında istatistiksel olarak anlamlı bir fark olmadı $\breve{g}_{1}$ belirlenmiştir $\left[\mathrm{F}_{(3-204)}=1.67, \mathrm{p}>\right.$.05].

Öğretmenlerin okul dışı çevrelere eğitim amaçlı gezi düzenleyebilme öz yeterlikleri ile hizmet süreleri arasındaki ilişki incelenmiş ve Tablo 8' de ve Tablo 9'da sunulmuştur. 
Tablo 8. Öğretmenlerin Okul Dışı Çevrelere Eğitim Amaçlı Gezi Düzenleyebilme ÖzYeterlikleri ile Hizmet Süresi Değişkenine İlişkin Betimsel İstatistikler

\begin{tabular}{lccc}
\hline Hizmet Süresi & & Öz-yeterlik & \\
& $\mathrm{N}$ & $\overline{\mathrm{x}}$ & $\mathrm{SS}$ \\
\hline $1-5$ y1l & 23 & 3.67 & 0.37 \\
$6-10$ yıl & 62 & 3.75 & 0.54 \\
$11-15$ yll & 57 & 3.81 & 0.52 \\
$16-20$ yıl & 43 & 3.63 & 0.51 \\
21 y1l ve üzeri & 23 & 3.69 & 0.50 \\
Toplam & 208 & 3.73 & 0.51 \\
\hline
\end{tabular}

Tablo 8 incelendiğinde hizmet süresi 1-5 yıl arasında olan ortaokul öğretmenlerinin okul dış1 çevrelere eğitim amaçlı gezi düzenleyebilme öz-yeterlik puan ortalamalarının ( $\overline{x=3.67), 6-10}$ y1l arasında olan öğretmenlerin puan ortalamalarının $(\overline{x=3.75), ~ 11-15 ~ y ı l ~ a r a s ı n d a ~ o l a n ~}$ öğretmenlerin puan ortalamalarının ( $\overline{\mathrm{x}}=3.81), 16-20$ yıl arasında olan öğretmenlerin puan ortalamalarının $(\bar{x}=3.63)$ ve hizmet süresi 21 yıl ve üzerinde olan öğretmenlerin puan ortalamalarının ise $(\bar{x}=3.63)$ olduğu tespit edilmiştir. Okul dışı çevrelere eğitim amaçlı gezi düzenleyebilme noktasında en yüksek öz-yeterlik puanına, hizmet süresi 11-15 yıl olan ortaokul öğretmenleri sahip iken en düşük öz yeterlik puanına ise 16-20 yıl hizmet süresi olan ortaokul öğretmenlerinin sahip oldukları görülmüştür.

Tablo 9. Öğretmenlerin Okul Dışı Çevrelere Eğitim Amaçlı Gezi Düzenleyebilme ÖzYeterliklerinin Hizmet Süresi Değişkenine İlişkin ANOVA Testi Sonuçları

\begin{tabular}{lccccc}
\hline & $\begin{array}{c}\text { Kareler } \\
\text { Toplamı }\end{array}$ & sd & $\begin{array}{c}\text { Kareler } \\
\text { Ortalaması }\end{array}$ & F & p \\
\hline Gruplar Arası & 0.91 & 4 & 0.23 & 0.87 & .48 \\
Gruplar İçi & 53,10 & 203 & 0.26 & & \\
Toplam & 54,01 & 207 & & & \\
\hline
\end{tabular}

Tablo 9 incelendiğinde ortaokul öğretmenlerinin okul dışı çevrelere eğitim amaçlı gezi düzenleyebilme öz-yeterlikleri ile hizmet süreleri arasında istatistiksel olarak anlamlı bir fark olmadığ $\breve{1}_{1}$ belirlenmiştir $\left[\mathrm{F}_{(4-203)}=0.87, \mathrm{p}>.05\right]$.

Öğretmenlerin branşlarına göre okul dişı öğrenme ortamlarını kullanma durumlarını incelemek için betimsel istatistikleri yapılmış ve Tablo 10' da sunulmuştur. 
Ortaokul Öğretmenlerinin Okul Dışı Çevrelere Gezi Düzenlemeye İlişkin Öz Yeterliklerinin Farklı Değişkenler Açısından İncelenmesi: Tokat İli Örneği

Tablo 10. Fen Bilimleri Öğretmenlerinin Okul Dışı Öğrenme Ortamlarını Kullanma Durumlarına Göre Frekans ve Yüzde Değerleri

\begin{tabular}{lcccc}
\hline & Fen B. & Matematik & Sosyal B. & Türkçe \\
\cline { 2 - 5 } Okul dışı öğrenme ortamları & $\mathrm{f}$ & $\mathrm{f}$ & $\mathrm{f}$ & $\mathrm{f}$ \\
\hline Okul Bahçesi & 38 & 36 & 22 & 41 \\
Planetaryum & ---- & ---- & 1 & 1 \\
Hayvanat Bahçesi & ---- & ---- & 2 & ---- \\
Bilim Merkezi & 7 & 5 & 3 & 3 \\
Doğal Anıtlar & 5 & 1 & 17 & 7 \\
Müzeler & 3 & 3 & 22 & 6 \\
Çeşitli Kurum ve Kuruluşlar & 18 & 24 & 22 & 39 \\
\hline
\end{tabular}

Araştırmaya katılan Fen Bilimleri öğretmenlerinin 38'inin (\%53.4) okul bahçesini, 18'inin (\%25.4) çeşitli kurum ve kuruluşları, 7'sinin (\%9.9) bilim merkezini, 5'inin (\%7) doğal anıtları ve 3'ünün de (\%4.2) müzeleri derslerinde kullandıkları tespit edilmiştir. Fen Bilimleri öğretmenlerinin en çok okul bahçesini kullandığı, planetaryum ve hayvanat bahçesini hiç kullanmadıkları görülmektedir.

Araştırmaya katılan Matematik öğretmenlerinin 36'sının (\%52.2) okul bahçesini, 24'ünün (\%34.8) çeşitli kurum ve kuruluşları 5'inin (\%7.2) bilim merkezini, 3'ünün (\%4.3) müzeleri ve 1 'inin de (\%1.4) doğal antları derslerinde kullandıkları tespit edilmiştir. Matematik öğretmenlerinin planetaryum ve hayvanat bahçesini derslerinde hiç kullanmadıklarını görülmektedir.

Sosyal Bilgiler öğretmenlerinin 22'sinin (\%24.7) okul bahçesini, müzeleri ve çeşitli kurum ve kuruluşları, 17'sinin (\%19.1) doğal anıtları, 3'ünün (\%3.4) bilim merkezini, 2'sinin (\%2.2) hayvanat bahçesini ve 1'inin de (\%1.1) planetaryumları derslerinde kullandığı tespit edilmiştir. Sosyal Bilgiler öğretmenlerinin en çok okul bahçesi, müzeler ve kurum kuruluşları, en az planetaryumu kullandıkları görülmektedir.

Araştırmaya katılan Türkçe öğretmenlerinin 41'inin (\%42.3) okul bahçesini, 39'unun (\%40.2) çeşitli kurum ve kuruluşları, 7'sinin (\%7.2) doğal anıtları, 6'sının (\%6.2) müzeleri, 3'ünün (\%3.1) bilim merkezini ve 1'inin de (\%1) planetaryumu derslerinde kullandıkları tespit edilmiştir. Türkçe öğretmenlerinin en çok okul bahçesini kullandığı, hayvanat bahçesini ise hiç kullanmadıkları görülmektedir.

Ortaokul öğretmenlerini okul dışı çevrelere eğitim amaçlı gezi düzenleme sürecinde kaygılandıran durumlar Tablo 11'de sunulmuştur. 
Tablo 11. Ortaokul Öğretmenlerini Gezi Düzenleme Sürecinde Kaygılandıran Durumlar

\begin{tabular}{|c|c|c|c|}
\hline Tema & Kategoriler & Kod & $\mathrm{f}$ \\
\hline \multirow{8}{*}{ 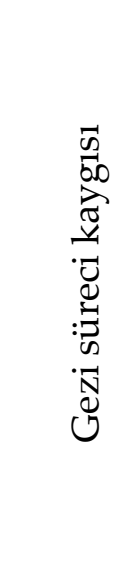 } & Güvenlik & Öğrencilerin güvenliği & 127 \\
\hline & & Öğrenci organizasyonu & 43 \\
\hline & Planlama & İhtiyaçların karşılanması & 38 \\
\hline & & İzin işlemleri & 24 \\
\hline & Sorumluluk & Tüm sorumluluğun öğretmene ait olması & 23 \\
\hline & İletişim & Velilerin davranışları & 19 \\
\hline & Amaç & Gezinin amacına uygunluğu & 12 \\
\hline & & Cevap vermeyen & 28 \\
\hline
\end{tabular}

Tablo 11 incelendiğinde ortaokul öğretmenlerinin 127'sinin öğrencilerin güvenliği, 43'ünün öğrencilerin organizasyonu, 38'inin ihtiyaçların karşılanması, 24'ünün izin işlemleri, 23'ünün öğrenci sorumluluğunun öğretmene ait olması, 19'unun velilerin tutumları ve 12'sinin de gezinin amacına uygun olup olmaması ile ilgili gezi düzenlemede çeşitli kaygılar yaşadığı belirlenmiştir. Bu kapsamda öğrencilerin güvenliği ile ilgili kayg1 yaşayan öğretmenlerden birisi "Öğrencilerin başına gelebilecek olumsuz durumlar beni kaygılandırıyor (K68)" derken bir diğeri "Kaza, hastalık, çocukların kaybolması vb. durumların olması kayg̨landırıor (E104)" şeklinde görüş bildirmiştir. Yine ihtiyaçların karşılanması ile ilgili kaygı yaşayan öğretmenlerden birisi "Yemeklerin öğrenciler üzerindeki etkisi beni kaygılandırıyor (K207)" derken bir diğeri "Uzun süreli gidilecek yerlerde konaklamayı sağlama konusunda kaygılanıyorum (E134)" şeklinde görüş bildirmiştir.

Öğrenci organizasyonu ile ilgili kaygı yaşadığını dile getiren öğretmenlerden birisi "Öğrencilerin takibi ve rehberlik yapmak beni kaygılandırıyor (K76)" derken bir diğeri "Gezi kurallarına uymayıp kendine veya başkasına zarar veren öğrencilerin olması, düzenin bozulması beni kaygılandırıyor (E36)" şeklinde görüş bildirmiştir. İzin işlemleri ile ilgili kaygı yaşayan öğretmenlerden birisi "Gezi için gerekli izinleri alıp alamayacă̆ım noktasında kayg̨lanıyorum (K125)" derken bir diğeri "İzin işlemlerinin uzun sürmesi ve evraklarda eksiklik olmasında korkuyorum (E126)" şeklinde görüş bildirmiştir. Öğrenci sorumluluğunun tamamen öğretmende olması ile ilgili kaygı duyan öğretmenlerden birisi “Öğrencilerin yaşayacağ problemlerde sorumluluğunun tamamen şahsıma yüklenmesi kaygılandırıyor (K198)" derken bir diğeri "Herhangi bir sıkıntı olduğu taktirde direk öğretmenin suçlanması ve disiplin soruşturması geçirmesi endişelendiriyor (E148)" şeklinde görüş bildirmiştir. Velilerin davranışları ile ilgili kayg1 yaşayan öğretmenlerden birisi "Gezi ile ilgili bilgi verilirken velilerin güvensizlik duymaları beni tedirgin ediyor (K120)" derken bir diğeri "Velilerin öğretmene karşı güvensiz olması ve tutumları kaygılandırıyor (E160)" şeklinde görüş bildirmiştir. Yine gezinin amacına uygunluğu ile ilgili zorluk çeken öğretmenlerden birisi "Gezinin amacının hizmet etmemesi kaygılandırıyor (K198)" derken bir diğeri "Öğrencilere gezinin amacının dışında bilgiler aktarmasından korkarım (E22)" şeklinde görüş bildirmiştir. Ortaokul öğretmenlerinin 28'i bu soruya cevap vermemiştir. 


\section{Tartışma}

Okul dışı gezilerin etkin olarak planlanmasında öğretmenlerin yeterli beceri ve bilgiye sahip olması (Bozdoğan, 2012; Tatar ve Bağrıyanık, 2012) ile birlikte okul dışı ortamlara gezi düzenlemeye ilişkin yeterliliklerinin de olması beklenmektedir. Yapılan bu çalışmada öğretim programlarındaki içerikler göz önüne alındığında okul dışı ortamları kullanma potansiyeli olan Fen Bilimleri, Türkçe, Matematik ve Sosyal Bilgiler öğretmenlerinin okul dışı çevrelere gezi düzenlemeye ilişkin öz yeterlikleri farklı değişkenler açısından incelenmiş ve elde edilen bulguları literatürdeki araştırma sonuçları ile tartışılmıştır.

Araştırmaya katılan öğretmenlerin okul dışı çevrelere eğitim amaçlı gezi düzenleyebilme noktasında kendilerini yeterli gördüğü belirlenmiştir. Öğretmenlerin cinsiyet değişkenine göre eğitim amaçlı gezi düzenleyebilme öz-yeterlik puanları incelendiğinde, erkek ve kadın öğretmenlerin puan ortalamalarının birbirine yakın olduğu ve aralarında anlamlı bir farkın olmadığı sonucuna ulaşılmıştır. Bozdoğan (2018) yaptığı çalışmada öğretmen adaylarının okul dışı çevrelere eğitim amaçlı gezi düzenleyebilme öz yeterlik puanları arasında cinsiyet değişkeni açısından benzer sonuçlara ulaşmıştır. Literatürde benzer sonuçlara rastlanmaktadır (Hamurcu ve diğ., 2019). Bu kapsamda araştırma sonuçlarının literatürle paralellik gösterdiği söylenebilir. Araştırmaya katılan öğretmenlerin okul dışı çevrelere eğitim amaçlı gezi düzenleyebilme öz yeterlilik puanlarının mezun oldukları bölüm değişkenine göre de anlamlı bir farklılık göstermediği belirlenmiştir. Bozdoğan (2018), yaptığı çalışmada Sosyal Bilgiler ve Fen Bilimleri öğretmen adaylarının okul dişı çevrelere eğitim amaçlı gezi düzenleyebilme öz yeterlik puanları arasında da anlamlı bir farkın olmadığını ancak Sınıf öğretmen adaylarının öz yeterlik puanlarının düşük olduğunu ve diğer iki bölüm öğrencileri lehine anlamlı bir farkın tespit edildiğini belirtmiştir. Bu çalışma sonucu da literatürle kısmen paralellik göstermekle birlikte farklı çalışmalarla durumun ortaya konması gerektiği görülmektedir. Eğitim fakültesi mezunları ile Fen edebiyat fakültesi mezunlarının okul dişı çevrelere eğitim amaçlı gezi düzenleyebilme öz yeterlik puanları arasında anlamlı bir fark olmamasına rağmen eğitim fakültesi mezunu öğretmenlerinin puanlarının daha yüksek olduğu sonucuna ulaşılmıştır. Bunun nedeni olarak eğitim fakültesi mezunu öğretmenlerin öğretim yöntemleri, sınıf yönetimi, planlama vs. gibi süreçlere ilişkin daha kapsamlı ve dört yıllık sürece yayılmış etkili pedagoji eğitim aldıklarından kaynaklanıyor olabileceği düşünülmektedir.

Öğretmenlerin eğitim düzeyleri ile okul dışı çevrelere eğitim amaçlı gezi düzenleyebilme özyeterlikleri puan ortalamaları karşılaştırıldığında lisansüstü eğitim yapan ortaokul öğretmenlerinin öz-yeterlikleri puan ortalamalarının, lisansüstü eğitim yapmayan ortaokul öğretmenlerinin puan ortalamalarından daha yüksek olduğu ve bu farkında istatistiksel olarak anlamlı bulunduğu belirlenmiştir. Sontay ve Karamustafaoğlu (2017) yaptıkları çalışmada araştırmamızın sonuçlarına benzer şekilde, yüksek lisans mezunu öğretmenlerin öz-yeterlilik inançlarının lisans mezunu öğretmenlere göre anlamlı farklılık oluşturacak derecede yüksek olduğunu tespit etmiştir. Bu farklılığın eğitim düzeyinin bireylerin rasyonelyaşantısal düşünme şekillerini kullanma seviyeleri üzerinde etkili bir değişken olmasından kaynaklanabileceği düşünülmektedir.

Araştırma kapsamında öğretmenlerin okul dışı çevrelere eğitim amaçlı gezi düzenleyebilme 
öz yeterlikleri ile gezi düzenleme sıklığına ilişkin sonuçları incelendiğinde gezi düzenleme sıklığının artmasına paralel olarak öz yeterlilik inancının arttığını ancak bu artışın istatistiksel olarak anlamlı olmadığı belirlenmiştir. Daha sık gezi düzenleyen öğretmenlerin kendilerini daha yeterli görmesinin temel nedeninin gezi sürecindeki tecrübelerinden kaynaklanabileceği düşünülmektedir. Çalışmanın bu sonucuna benzer şekilde Temel ve Kölemen'in (2021) yapmış oldukları çalışmada da öğretmenlerin yıl içerisinde gezi gerçekleştirme davranışının artmasıyla paralel olarak öz yeterlilik inancının arttığı sonucuna varmışlardır. Öğretmenlerin gezi düzenleme sıklığı açısından bakıldığında; öğretmenlerin çoğunluğunun daha az gezi düzenledikleri sonucuna ulaşılmıştır. Bunun nedeninin öğrenci velilerinden ve kurumdan izin alma süreci gibi bürokratik, gezi esnasında öğrencilerin kontrolünün sağlanması gibi güvenliğe ilişkin nedenlerden kaynaklandığı düşünülmektedir.

Araştırmaya katılan öğretmenlerin okul dışı çevrelere eğitim amaçlı gezi düzenleyebilme özyeterlikleri ile hizmet süresi değişkeni arasında istatistiksel olarak anlamlı bir fark olmadığ sonucuna ulaşılmıştır. Farklı hizmet sürelerine sahip öğretmenlerin öz yeterlik puanları birbirine yakıp çıkmış olup, bu sonucun mesleki deneyim yılının öğretmenlerin öz yeterlilik inançları üzerinde bir etkisi olmadığını göstermektedir. Nitekim Pas, Bradshaw ve Hershfeldt (2012) ve Yılmaz ve Çokluk-Bökeoğlu, (2008) yaptıkları çalışmalarda da bu çalışmanın sonucuna benzer şekilde öğretmenlerin öz yeterlilik inançlarının mesleki deneyime göre farklılık oluşturmadığı sonucuna varmışlardır.

Fen bilimleri öğretmenlerinin hangi okul dışı öğrenme ortamlarını daha sık tercih ettiklerine yönelik görüşleri incelendiğinde; en sık okul bahçesini, daha sonra sırasıyla çeşitli kurum ve kuruluşları, bilim merkezlerini, doğal anıtları ve müzeleri derslerinde kullandıkları, planetaryum ve hayvanat bahçesini hiç kullanmadıkları tespit edilmiştir. Öğretmenlerin daha sık okul bahçesi ve yakın çevredeki çeşitli kurum ve kuruluşları tercih etmesinin nedeni olarak daha kolay ulaşılabilir olması ve öğrenci kontrolünün daha kolay sağlanmasından kaynaklandığı düşünülmektedir. Nitekim fen bilimleri öğretmenlerinin okul dışı çevrelere eğitim amaçlı gezi düzenleme sürecinde karşılaşılan zorluklar arasında kurumdan izin alma ile öğrencilerin kontrolünü sağlamak gibi bürokrasi ve disiplin konusunda zorluk yaşadıklarını belirtmişlerdir. Bozdoğan, Okur ve Kasap (2015), yapmış oldukları çalışmada da planlı olarak yapılan gezilerde öğretmenlerin en çok bürokratik işler ve ulaşım vasıtalarının ayarlanması konusunda zorluk yaşadıkları sonucuna varmışlardır. Yapılan bir diğer çalışmada da okulun imkânlarının kısıtlı olmasından dolayı fen bilimleri öğretmenlerinin genel olarak okul bahçelerini kullandıkları ifade edilmektedir (Büyükkaynak, Ok ve Aslan, 2016).

Araştırmaya katılan Türkçe öğretmenlerinin hangi okul dışı öğrenme ortamlarını daha sık tercih ettiklerine yönelik görüşleri incelendiğinde, en sık okul bahçesini, daha sonra sırasıyla çeşitli kurum ve kuruluşları, kullandıkları sonucuna ulaşılmıştır. Alan yazı incelendiğinde Türkçe öğretmenlerine ilişkin okul dışı faaliyetleri kapsayan çalışmaların çok sınırlı olduğu görülmüştür. Yapılan bu çalışmada Türkçe öğretmenlerin okul bahçesi, bilim merkezlerini, doğal anıtları, müzeleri, bilim merkezlerini ve planetaryum gibi farklı türlerde okul dışı öğrenme ortamlarını kullandığı belirlenmiş olsa da Bayburtlu (2020) yapmış olduğu çalışmada öğretmenlerin Türkçe dersinin ünitelendirilmiş yıllık planlarında sadece müze ve kütüphane gibi okul dışı ortamları kullandıkları görülmektedir. Bu farklılığın öğretmenlerin maddi imkânsızlıklar, zaman yetersizliği, öğretim programının yoğunluğu ve güvenlikle ilgili 
kaygılardan kaynaklanabileceği düşünülmektedir. Nitekim Demir (2007) ve Kılıç (2018) yapmış oldukları çalışmalarda öğretmenlerin maddi imkânsılılklar, zaman yetersizliği, öğretim programının yoğunluğu ve güvenlik ile ilgili kaygılar gibi gerekçelerle derslerinde okul dışı öğrenme ortamlarını çok kullanamadıklarını belirtmişlerdir.

Araştırmaya katılan Sosyal Bilgiler öğretmenlerinin derslerinde en sık okul bahçesini, müzeleri ve çeşitli kurum ve kuruluşları, en az ise planetaryumları kullandıkları belirlenmiştir. Malkoç ve Kaya (2015) yapmış oldukları çalışmada araştırma sonucumuza benzer şeklide sosyal bilgiler öğretmenlerinin eğitim ve öğretim için yararlanılabilecek sınıf dışı okul ortamları çerçevesinde en çok okul bahçesi, kütüphane, spor salonlarını kullandıklarını dile getirmişlerdir. Topçu (2017) sosyal bilgiler öğretmenleri ile yapmış olduğu çalışmada da öğretmenlerin okul dışı okul dışı öğrenme ortamlarında izin sıkıntısı, ulaşım ve güvenlik problemleri ile öğrenci sayılarının fazla olması gibi zorluklarla karşılaştıklarını belirtmişlerdir.

Diğer branş öğretmenlerinde olduğu gibi Matematik öğretmenlerinin de en sık yararlandıkları okul dışı ortamın okul bahçesi olduğu belirlenmiştir. Öğretmenlerin okul dışı çevrelere eğitim amaçlı gezi düzenleme sürecinde gerekli kurum ve velilerden izin alamama, gezi yapılacak bölgeye ulaşımın sağlanmasında gerekli aracı tahsis edememe gibi birçok zorluklar yaşadıklarından dolayı ulaşılabilirliği daha kolay olan okul dışı ortamlardan okul bahçesini seçtikleri sonucuna ulaşılmıştır. Kır, Kaftaoğlu ve Aksu (2021) yapmış oldukları çalışmada da matematik öğretmenlerinin kolay ulaşılabilir olması nedeniyle en çok kullandıkları okul dışı öğrenme ortamının okul bahçesi olduğunu belirtmişlerdir. 4 farklı branşta da öğretmenlerin en sık okul bahçelerini tercih ettiği tespit edilmiştir. Ancak okul dışı ortamlarda okul bahçelerinin kullanımı çeşitli sorunları beraberinde getirebilmektedir. Yapılan bir çalışmada (Gülen, 2021) okul dişı ortam olarak okul bahçesi kullanmanın öğrencilerdeki dikkat dağınıklığı ve mevsimsel etmenler, güvenlik eksikleri, açık alanda duyma ve not alma, araçgereç yetersizliği gibi sorunları da beraberinde getirdiği belirtilmiştir.

Okul dışı öğrenme ortamları teorik bilgiyi daha eğlenceli hale getirmesi, derse ilgi ve alakayı arttırması, uygulamalı öğrenmeyi etkin kılması, kalıcı öğrenmeyi sağlaması, öğrenmeyi kolaylaştırarak başarıyı arttırması gibi birçok yararının olmasına rağmen öğretmenler okul dışı çevrelere eğitim amaçlı gezi düzenleme sürecini uygulamada birçok zorlukla karşılaşabilmektedirler (Demirtaş ve Çayır, 2021; Tal ve Morag, 2009). Araştırmada yer alan tüm branş öğretmenlerinin gezi öncesinde yaşadıkları zorluklar incelendiğinde; izin alma gibi bürokratik nedenler, maddi imkanların yetersiz oluşundan dolayı araç bulmakta sıkıntı yaşama gibi ulaşıma ilişkin nedenler, Türkçe öğretmenlerinin diğer branşlardan farklı olarak birde planlamaya ilişkin zorluklar yaşadıkları belirlenmiştir. Gezi esnasında ise en çok öğrencilerin kontrolünü sağlayamama ve kurallara uyulmamasına ilişkin zorluklarla karşılaştıkları belirlenirken gezi sonrası istenilen kazanımların sağlanıp sağlanamadığını tespit etmede ve öğrencilerin evlerine sağ salim ulaşmalarını sağlanması konusunda zorluk yaşadıkları tespit edilmiştir. Çalışma sonuçlarına benzer şekilde Akgül ve Arabacı (2020) yapmış oldukları çalışmada fen bilimleri öğretmenlerinin okul dışı öğretim sürecinde öğrenci kontrolü, uzaklık ve ulaşım sorunları, idari engeller ve resmi yazışmalar gibi nedenlerden dolayı zorluklar yaşadıkları, Gürsoy (2018) fen bilimleri öğretmen adaylarının gezi öncesinde en çok ulaşım ve gezi için gerekli bürokratik işler konusunda zorluk yaşadıklarını belirtmişlerdir. Ocak ve Korkmaz (2018) tarafından yapılan araştırmada da ulaşım sıkıntısı, 
resmi yazışmalar ile idari izinde yaşanan zorluklar ve dikkat dağınıklığı gibi nedenlerden dolayı problemler yaşadıklarını belirtmişlerdir. Topçu'nun (2017) yapmış olduğu çalışmada bu araştırma sonuçlarına benzer şekilde; sosyal bilgiler öğretmen adaylarının okul dışı öğrenme ortamları sürecinde izin sıkıntısı, ulaşım ve güvenlik sorunları ile karşılaştıklarını ifade etmiştir. Kır, Kaftaoğlu ve Aksu'nun (2021) yapmış oldukları çalışmada da, çalışma sonuçlarımıza paralel şekilde matematik öğretmenlerinin okul dışı öğrenme ortamları sürecinde daha çok sağlık ve güvenlik konusunda zorluklar yaşadıklarını ifade etmişlerdir.

Araştırmada yer alan bütün branş öğretmenlerinin (Fen Bilimleri, Sosyal Bilgiler, Türkçe ve Matematik) büyük çoğunluğunun gezi düzenleme sürecinde öğrencilerin güvenliği konusunda kaygılandıkları belirlenmiştir. Nitekim okul dışı ortamlara ilişkin yaşadıkları zorluklara ilişkin verdikleri cevaplarda da öğretmenlerin büyük çoğunluğu öğrencilerin gezi esnasında kontrolünün sağlanması ile gezi sonrasında öğrencilerin evlerine sağ salim evlerine ulaşmalarının sağlanması gibi güvenliğe ilişkin yanıtlar vermesi bu kaygının temel nedenini açıklamaktadır. Yapılan bu araştırma sonucuna benzer şekilde Bozdoğan $(2012 ; 2018)$ yapmış olduğu iki farklı çalışmada öğretmen adaylarının okul dışı ortamlara gezi düzenleme sürecinde en çok gezi güvenliği konusunda kaygılandığını tespit etmiştir. Tatar ve Bağrıyanık (2012) çalışmalarında da öğretmenlerin büyük çoğunluğunun okul dışı aktiviteleri gerçekleştirirken öğrencilerin güvenliği nedeniyle kaygı yaşadıklarını belirtmişlerdir. Atmaca (2012), tarafından yapılan araştırmada, okul dışı öğrenme faaliyetlerinin başarı ile tamamlanabilmesi için sadece öğrenme alanlarına ilişkin planların değil, güvenlik ve organizasyon konusunda da hazırlıkların yapılmasının gerekliliğini ortaya koymuştur. $\mathrm{Bu}$ bağlamda okul dışı ortamlara gezi planlamasında güvenlik ve emniyet açısından risk faktörlerinin belirlenmesi ve bu riskleri en aza indirecek planlamaların yapılaması önemlidir.

Araştırmada elde edilen bu sonuçlar doğrultusunda şu öneriler getirilebilir;

1. Öğretmenler lisansüstü eğitimlere teşvik edilebilir ve MEB tarafından alanında uzmanlaşmış öğretmenlerin okul dişı ortamlara gezi düzenlemeye ilişkin eğitim faaliyetlerini üstlenmesi sağlanabilir.

2. Gezi düzenleme sıklığı daha fazla olan öğretmenlerin deneyimi az ve göreve yeni başlayan öğretmenlere deneyimlerini ve düşüncelerini hizmet içi eğitim seminerleri ile aktarabilir.

3. Okul bahçelerinin daha iyi bir görünüşe sahip olması için beton ve asfalt yüzeylerden kaçınılmalı, peyzaj projeleri teşvik edilerek, doğanın tabiatına özgü tasarlanmış geniş çim alanları ve okul bahçesi ihata duvarı boyunca iklim bölgesine uygun ağaçları içeren düzenlemeler yapılabilir

4. İzin alma sürecinde kolaylık olabilmesi için velilere okul dışı etkinlikler ve önemi konusunda bilgilendirilerek dönem başlarında tüm okul dışı etkinlikler için tek seferde izin alınabilir. Ayrıca öğretmenlerin okul dışı ortamlardan daha çok faydalanılabilmesi için MEB ile temasa geçilerek izin prosedürleri daha basitleştirilebilir.

5. Öğretmenlerin gezi düzenleme sürecinde öğrencilerin güvenlik durumdan kaynaklanacak kaygıları önleyebilmek için; alan gezilerine uzman rehberlerin katılması önerilebilir.

6. Bu çalışmanın daha büyük örneklem gruplarıyla, hem bilimsel süreç becerileri hem de 
Ortaokul Öğretmenlerinin Okul Dışı Çevrelere Gezi Düzenlemeye İlişkin Öz Yeterliklerinin Farklı Değişkenler Açısından İncelenmesi: Tokat İli Örneği

okul dışı öğrenme ortamlarının farklı değişkenler üzerine etkisini gösteren daha kapsamlı çalışmalar yürütülmesi önerilebilir.

\section{Araştırmacıların Katkı Oranı}

$\mathrm{Bu}$ çalışma birinci yazarın ikinci yazar danışmanlığında gerçekleştirdiği yüksek lisans tezinden üretilmiştir. Dolayısıyla çalışmanın tüm aşamaları iki yazar tarafından beraber ve eşit oranda katkı verilerek hazırlanmıştır.

\section{Çatışma Beyanı}

Yazarlar potansiyel bir çıkar çatışması olmadığını beyan ederler.

\section{Kaynakça}

Akgül, G. D. ve Arabacı, S. (2020). Okul dışı öğrenme ortamlarına yönelik fen bilgisi öğretmenlerinin görüşleri. Uluslararası Eğitim Araştırmacıları Dergisi, 3(2), 276-291.

Atmaca, S. (2012). Derslik dışı fen etkinlikleri ve bu etkinliklere dayalı öğretimin öğretmen adayları üzerindeki etkileri. Yayımlanmamış doktora tezi. Hacettepe Üniversitesi Sosyal Bilimler Enstitüsü, Ankara.

Avcı, G. ve Gümüş, N. (2019). Sınıf dışı eğitim etkinliklerine yönelik öğrenci görüşleri. Turkish Studies- Educational Sciences, 14(3), 351-377.

Bandura, A. (1997). Self-efficacy: The exercise of control. New York:W.H. Freeman and Company.

Bayburtlu, Y. S. (2020). Okul dışı öğrenme ortamlarının türkçe dersi ünitelendirilmiş yıllık planlarına yansımaları. İnsan ve Toplum Bilimleri Araştırmaları Dergisi, 9(5), 3835-3852.

Bozdoğan, A. E. (2008). Fen Bilgisi öğretmen adaylarının bilim merkezlerini fen öğretimi açısından değerlendirmesi: Feza Gürsey Bilim Merkezi örneği. Uludă̆ Üniversitesi Ĕ̆itim Fakültesi Dergisi, 21(1), 19-41.

Bozdoğan, A. E. (2012). Eğitim amaçlı gezilerin planlanmasına ilişkin fen bilgisi öğretmen adaylarının uygulamaları: Altı farklı alan gezisinin değerlendirilmesi. Kuram ve Uygulamada Ĕ̈itim Bilimleri, 12(2), 1050-1072.

Bozdoğan, A. E. (2015). Okul dışı çevrelere eğitim amaçlı gezi düzenleyebilme öz-yeterlik inancı ölçeğinin geliştirilmesi. Kuramsal Ĕ̆itim Bilim Dergisi, 9(1), 111-129.

Bozdoğan, A. E. (2016). Development of self-efficacy belief scale for planning and organizing educational trips to out of school settings. Journal of Theoretical Educational Science, 9(1), 111-129. 
Bozdoğan, A. E. (2018). The effects of elective course designed with different contents on preservice science teachers' self-efficacy beliefs and knowledge about organizing curriculum based field trips. Journal of Baltic Science Education, 17(3), 446-461.

Bozdoğan, A. E., Okur, A. ve Kasap, G. (2015). Planlı bir alan gezisi için örnek uygulama: Bir fabrika gezisi. Karadeniz Sosyal Bilimleri Dergisi, 7(02).

Büyükkaynak, E., Ok, Z. ve Aslan, O. (2016). Fen bilimleri öğretmenlerinin fen eğitiminde okul dışı öğrenme ortamlarına yönelik görüşleri. Kafkas Üniversitesi Sosyal Bilimler Enstitüsü Dergisi, 1, 43-60.

Çepni, S. (2007). Araştırma ve Proje Çalışmalarına Giriş. Trabzon: Celepler Matbaacılık.

Çiçek, Ö. ve Saraç, E. (2017). Fen Bilimleri öğretmenlerinin okul dışı öğrenme ortamlarındaki yaşantıları ile ilgili görüşleri. Ahi Evran Üniversitesi Kırşehir Eğitim Fakültesi Dergisi (KEFAD), 3(18), 504-522.

Demir, M. K. (2007). Sınıf öğretmenlerinin hayat bilgisi ve sosyal bilgiler derslerinde gözlem gezisi yöntemini uygulama durumları. Türk Eğitim Bilimleri Dergisi, 5 (2), 323-341.

Demirel, İ. (2020). Sınıf eğitimi öğretmen adaylarının müzelerde eğitim uygulamalarına yönelik öz yeterlikleri. Abant İzzet Baysal Üniversitesi Ĕ̆itim Fakültesi Dergisi, 20(1), 585604.

Demirtaş, S. ve Çayır N. A. (2021). Sınıf öğretmenlerinin sınıf dışı eğitim etkinlikleri projesine yönelik deneyimleri üzerine bir araştırma. Ĕ̆itim ve Bilim, 1-30.

Erten, Z. ve Taş̧̧i, G. (2016). Fen Bilgisi dersine yönelik okul dışı öğrenme ortamları etkinliklerinin geliştirilmesi ve öğrencilerin bilimsel süreç becerilerine etkisinin değerlendirilmesi. Erzincan Üniversitesi Ĕ̆itim Fakültesi Dergisi,18 (2), 638-657.

Eschenhagen, D., Katmann, U. ve Rodi, D. (2008). Fachdidaktik biologie. (4th edition) (Ed. Ulrich Kattman). Koeln: Aulis Verlag Deubner.

Gerber, B.L., Marek, E.A. ve Cavallo, A.M.L. (2001). Development of an informal learning opportunities assay. International Journal of Science Education 23(6), 569-583.

Gülen, G. (2021). Fen bilimleri öğretmenlerinin derslerinde okul bahçelerini kullanma durumlarının incelenmesi: Tokat ili örneği. Yayınlanmamış yüksek lisans tezi, Gaziosmanpaşa Üniversitesi Eğitim Bilimleri Enstitüsü, Tokat.

Gürsoy, G. (2018). Fen Öğretiminde okul dışı öğrenme ortamları. Electronic Turkish Studies, 13(11). 623-649.

Hamurcu, H., Karcı, G., Göbeklioğlu, G., Aymak, Ö., Atalay, S. ve Topaloğlu, S. (2019). Selfefficacy beliefs of preservice primary school teachers about organization of educational school trips. Journal of Research in Informal Environments, 4(2), 102-116. 
İşlek, D. (2019). Okul öncesi öğretmen adaylarının müzelerin eğitim ortamı olarak kullanılmasına ilişkin öz-yeterlik inançlarının ve görüşlerinin incelenmesi. Elementary Education Online, 18 (4), 1434-1447.

Karamustafaoğlu, O. ve Ermiş, M. (2020). Biyoteknoloji konusunun okul dişı fen ortaminda öğretimine yönelik öğrenci görüşleri. Eskişehir Osmangazi Üniversitesi Türk Dünyası Uygulama ve Araştırma Merkezi (ESTÜDAM) Ĕ̆itim Dergisi, 5(1), 92- 114.

Kılıç, A. (2018). Hayat bilgisi dersi, “dün, bugün, yarın” temasında sözlü ve yerel tarih etkinliklerinin değerlendirilmesi. Yayınlanmamış yüksek lisans tezi, İstanbul Üniversitesi Eğitim Bilimleri Enstitüsü, İstanbul.

Kır, H., Kalfaoğlu, M. ve Aksu, H. (2021). Matematik öğretmenlerinin okul dışı öğrenme ortamlarının kullanımına yönelik görüssleri. International Journal of Educational Studies in Mathematics, 8(1), 59-76.

Luszczynska, Gutiérrez-Doña ve Schwarzer, (2005). General self-efficacy in various domains of human functioning: Evindece from five Countries. International Journal of Psychology, 40(2), 80-89.

Malkoç, S. ve Kaya, E. (2015). Sosyal Bilgiler öğretiminde sınıf dışı okul ortamlarının kullanımı. İlköğretim Online Dergisi, 14(3), 1079-1095.

MEB (2018). Talim ve Terbiye Kurulu Başkanlığı, ilköğretim fen bilimleri dersi (4, 5, 6, 7 ve 8. Sinıflar) ögretim programı. Ankara: MEB Yayınları.

Melber, L.H. ve Abraham, L.M. (1999). Beyond the classroom: Linking with informal education. Science Activities, 36, 3-4.

Ocak, İ. ve Korkmaz Ç. (2018). Fen bilimleri ve okul öncesi öğretmenlerinin okul dışı öğrenme ortamları hakkındaki görüşlerinin incelenmesi. International Journal of Field Education, 4 (1), 18-38.

Okur, A., Uzoğlu, M., ve Bozdoğan, A. E. (2019). The effect of planned trips to zoos on learning in science education and determining student remarks about the trip process. Illkögr retim Online, 18(4), 1418-1433.

Pas, E. T., Bradshaw, C. P. ve Hershfeldt, P. A. (2012). Teacher-and school-level predictors of teacher efficacy and burnout: Identifying potential areas for support. Journal of school psychology, 50(1), 129-145.

Saraç, H. (2017). Türkiye'de okul dışı öğrenme ortamlarına ilişkin yapılan araştırmalar: İçerik analizi çalışması. Eğitim Kuram ve Uygulama Araştırmaları Dergisi, 3(2), 60-81.

Sarıoğlan, A. B. ve Küçüközer, H. (2017). Fen Bilgisi öğretmen adaylarının okul dışı öğrenme ortamları ile ilgili görüşlerinin araştırılması. Informal Ortamlarda Araştırmalar Dergisi, 2(1), 1-15. 
Sontay, G. ve Karamustafaoğlu, O. (2017). Fen bilimleri öğretmenlerinin gezi düzenlemeye ilişkin öz-yeterlilik inançlarının incelenmesi. Hacettepe Üniversitesi Ĕ̆itim Fakültesi Dergisi, 32(4), 863-879.

Sontay, G., Tutar, M. ve Karamustafaoğlu, O. (2016). Okul dışı öğrenme ortamları ile Fen öğretimi hakkında öğrenci görüşleri: Planetaryum gezisi. Informal Ortamlarda Araştırmalar Dergisi. 1(1), 1-24.

Sturm, H., ve Bogner, F.X. (2010). Learning at workstations in two different environments: A Museum and a classroom. Studies in Educational Evaluation, 36, 14-19.

Tal, T., Morag, O. (2009). Reflective practice as a means for preparing to teach outdoors in an ecological garden. Journal of Science Teacher Education, 20, 245- 262.

Tatar, N. ve Bağrıyanık, K. B. (2012). Fen ve Teknoloji dersi öğretmenlerinin okul dışı eğitime yönelik görüşleri. İlköğretim Online, 11(4), 883-896.

Temel F. ve Kölemen E.B. (2021). Okul öncesi öğretmenlerin alan gezisi düzenlemeye ilişkin öz- yeterlilik inançlarının incelenmesi. International Primary Educational Research Journal, 5(1), 46-58.

Topçu, E. (2017). Sosyal bilgiler öğretiminde okul dışı öğrenme ortamları: Öğretmen adayları ile fenomenolojik bir çalışma. International Education Studies, 10(7), 1-17.

Usta, E. ve Korkmaz, Ö. (2010). Pre-service teachers' computer competencies, perception of technology use and attitudes toward teaching career. Journal of Human Sciences, 7(1), 1335-1349.

Uzbilir Özçelik, G. (2018). Okul öncesi ve sını öğretmenlerinin bilimsel alan gezisi yapmaya ilişkin öz yeterliklerinin ve yaparken yaşadıkları zorluklar hakkında Görüşlerinin incelenmesi. Yayımlanmamış yüksek lisans tezi. İstanbul Aydın Üniversitesi Sosyal Bilimler Enstitüsü, İstanbul.

Yıldırım, F. ve İlhan, İ. Ö. (2010). Genel Öz-yeterlilik ölçeği Türkçe formunun geçerlilik ve güvenilirlik çalışması. Türk Psikiyatri Dergisi, 21(4), 301-308.

Yılmaz, K. ve Çokluk-Bökeoğlu, Ö. (2008). İlköğretim okulu öğretmenlerinin yeterlik inançları. Ankara Üniversitesi Ĕ̆itim Bilimleri Fakültesi Dergisi, 41(2), 143-167. 